\title{
Analysis of Financial Performance of Foreign Banks Having Branches in Turkey by TOPSIS and ELECTRE Methods
}

\author{
(Research Article)
}

Türkiye'de Şube Açan Yabancı Sermayeli Bankaların Finansal Performanslarinin TOPSIS ve ELECTRE Yöntemleriyle Analizi

Doi: 10.29023/alanyaakademik.871031

\section{Tunga BOZDOĞAN}

Doç. Dr., Eskişehir Osmangazi Üniversitesi, İBF., Işsletme Bölümü

tunga.bozdogan26@gmail.com

Orcid No: 0000-0002-1651-9865

Corresponding author: 05337313095

\section{Alper ODABAŞ}

Doç. Dr., Eskişehir Osmangazi Üniversitesi, Fen Edebiyat Fakültesi, Matematik ve

Bilgisayar Bilimleri Bölümü

aodabas@ogu.edu.tr

Orcid No: 0000-0002-4361-3056

\author{
Abdul Haq SHEGIWAL \\ Eskişehir Osmangazi Üniversitesi, Sosyal Bilimler Enstitüsü \\ a.haq1988@live.com
}

Orcid No: 0000-0003-0938-2626

How to cite this article: Bozdoğan, T., Odabaş, A. \& Shegiwal, A. H. (2021). "Analysis of Financial Performance of Foreign Banks Having Branches in Turkey by TOPSIS and ELECTRE Methods". Alanya Academic Review, 5(2), pp.1049-1067.

\section{Keywords:}

\section{Financial \\ Performance, \\ Bank, \\ CAMELS, \\ TOPSIS Method, \\ ELECTRE Method \\ Jel Classification: \\ D81, G21, M41.}

Received: 30.01 .2021

Accepted: 26.03.2021

\begin{abstract}
Effective performance evaluation is an important indicator of the success of every business particularly the banking sector. Banks are one of the most fundamental elements of the financial system. The financial structures of banks should be measured and evaluated accurately, the results should be analyzed salubriously and presented to the relevant users. The performance of each bank is evaluated by financial criteria which are ranked according to their financial performance. This is important both for the bank and the decision makers in the banking sector in which it operates. The aim of this study is to evaluate the financial performance of foreign banks having branches in Turkey. In the study, in Turkey four foreign banks having branches and Ziraat Bank with the largest assets were analyzed. The data were obtained from the annual reports of banks between 2014 and 2018. CAMELS criteria were used as financial performance indicators in the study. TOPSIS (Technique for Order Preference by Similarity to Ideal Solution) and ELECTRE (Elimination and Choice Translating Reality) which are multi-criteria decision-making methods were used to evaluate the financial performance of these banks. As a result of the application of these
\end{abstract}


methods, financial performance values of banks and success values for each year were found. The results obtained by the analysis made in both methods are presented in a comparative perspective.

\section{INTRODUCTION}

In the journal stated that bank is very ancient institution which contributes towards the development of economy and its treatment as an important service industry in modern world (Nimalathasan, 2008: 141). For most businesses, bank is one of the most sources of financing institutions. The banking sector is great importance in terms of national economy. Banks should use their resources effectively and efficiently due to competition in sector. Therefore the performances of banks should be evaluated and measures must be taken in their performances enhancing as a result of evaluation (Çalışkan et al., 2016: 85). It is important for financial information users and every central bank to comprehend the financial performances of banks and financial institutions operating under the specific license issued to them. Therefore, all the banks are required to carry out transparent and sound banking activities and follow the guidelines and regulations set by the regulators or the central bank. It is essential for the central bank and those who run the national economy to evaluate their financial performance because banks enter every corner of the country and have been extending a helping hand in the growth of the economy.

The collective supposition that reinforces a lot of the financial performances research and as well as discussions is enhancing financial performances and shall lead to better functions and activities of organizations (Nimalathasan, 2008: 141). Financial performance of a bank is important in comprehensive sense that denotes to the degree to which financial objectives have been accomplished and it a significant aspect in the finance risk management and this process measures results of the policies of bank as well operations in the monetary term. Therefore, it is used to measure overall financial health of a bank over a given period of time and could also be used to make comparison between similar banks in the same industry or in order to compare industries or sector wise in accumulation.

There are different methods, applications and criteria used for evaluating the financial performance of banks. One of them is CAMELS. This rating system was developed in the United States in 1979 as Supervisory Rating System (SRS) that will assist to analyze overall financial situation of banks. On the other hand, the UFIRS which stands for Uniform Financial Institutions Rating System was also developed by the Federal Financial Institutions Examinations Council known as (FFIEC) on November 13, 1979. Initially it began in the United States. However, it has now started to implement worldwide by different banking supervisory regulators with the recommendations of the U.S. Federal Reserves. These ratings are merely open to the top level management in order to avoid possible bankrupt and it is not publically rereleased. Hence, CAMELS stands for C. Capital Adequacy, A. Assets, M. Management Quality, E. Earnings, L. Liquidity and S. Sensitivity to Market Risk (Manju et al., 2017:3).

The main objective of this study is to evaluate the financial performances of foreign banks having branches opened in the Republic of Turkey. Therefore, in this study, firstly CAMELS criteria were determined in order to measure the financial performances of these banks and additional two methods (TOPSIS and ELECTRE) which are multi-criteria decision making techniques were used to evaluate and understand the financial performances of these banks 1050 
through the years 2014-2018. Hence, the research is based on the evaluation of the financial performance of five banks. From these banks, four of them are foreign banks with their branches operating in Turkey are Habib Bank, Pakistan, Intesa Sanpaolo Bank, Italy, Societe Generale, France and JPMorgan Chase Bank, U.S.A. According to the data from The Banks Association of Turkey (TBB), total five foreign banks having branches opened in the Republic of Turkey are found. However, the data of Mellat Bank, Iran was not available and as a result, it was excluded from the evaluation process. Therefore, the Ziraat Bank, which is the largest based on assets in Turkey, was included in this study. The results obtained by the analysis made in both TOPSIS and ELECTRE methods are presented in a comparative perspective.

\section{LITERATURE REVIEW}

The Literature research based on the topic is done with the evaluation of financial performance of banks in three parts with CAMELS components, the TOPSIS method and ELECTRE method which were attempted to be summarized in bank performances.

A) These are the summaries on the study on evaluations of financial performances of banks with CAMELS components. Guan, et al. (2019) China, Khatri (2019) and Sangmi et al. (2010) India, Rahman et al. (2018) and Ahsan (2016) Bangladesh, Munir et al. (2017) Indonesia and Malaysia, Rozzani et al. (2013) Malaysia, Mousa (2016) Jordan, Komorowski et al. (2016) Bosnia and Herzegovina, Rostami (2015) Iran, Ibrahim (2015) United Arab Emirates, Kumar et al. (2015) United Arab Emirates, Qatar, Bahrain, Kuwait, Jaffar et al. (2011) Pakistan, Karaca et al. (2018), Şendurur et al. (2018), Karaçor, et al. (2017), Ege, et al. (2015), Karapınar et al. (2015) and Gümüş et al. (2015) these studies have been done over Turkish banks.

B) The summaries provided below are the studies in the performance of banks using TOPSIS method; Sarı, (2020), Kaygusuz, et al. (2020), Bozdoğan, et al. (2018), Anyaeche et al. (2018), Siew et al. (2017), Wanke et al. (2017), Wanke et al. (2016), Dinçer, et al. (2016), Dash (2016), Ghasempour et al. (2016), Li et al. (2014), Amile et al. (2013), Hemmati et al. (2013), Akkoç et al. (2013), Dinçer et al. (2011), Demireli (2010) and Seçme et al. (2009) these studies have been done for the evaluation of banks performances with TOPSIS method.

C) The summaries provided below are the studies in the performance of banks using ELECTRE method; Bayyurt (2013), Dinçer, et al. (2016) and Çağıl, (2011), Kılıç, (2006) tried to evaluate the performances of banks by using ELECTRE Method. In the literature, Chaudhuri et al. (2014) used both TOPSIS, ELECTRE and VIKOR methods to make evaluation in the performances of both public and private banks in India and compared them with the values used by Reserve Bank of India. In the literature research, it is clear that TOPSIS method is used more than ELECTRE method in the studies. Therefore, in this study, both TOPSIS and ELECTRE methods are used together to evaluate the financial performances of these banks.

\section{EVALUATION OF FINANCIAL PERFORMANCE WITH CAMELS IN BANKS}

It is stated that the concept of financial performances as well research into its measurement are well advanced in the management and finance fields. A recent rating system known as 
CAMELS is now widely used in order to evaluate the performances of financial institutions, but more particularly banks (Nimalathasan, 2008: 142).

The CAMELS system concentrates on the assessment of banking system by examining its financial statements, like the balance sheet and income statement (profit and loss statement). Consequently, it observes the dynamic aspect of the financial institutions (Christopoulos, et al., 2011:12). The performances of banking sector with CAMELS incorporates evaluation and analysis of six very important dimensions of the banking operations. Thus, CAMELS incorporates a set of performance measures that gives a complete comprehensive opinion of the banks based on rates (Kaygusuz, et al., 2020: 75; Rozzani et al., 2013: 40; Nimalathasan, 2008: 142; Ghasempour et al., 2016: 54-55; Manju et al., 2017: 3-4).

The basic conceptual view on the financial performances and research into its measurement is very well advanced within the finance and management fields. In a recent well-judged technique known as CAMELS rating system is now used widely for evaluating performance of banks and financial institutions (Nimalathasan, 2008: 142).

Following CAMELS components have been used in the evaluation of these banks.

1. C (Capital Adequacy)

2. A (Assets Quality)

3. M (Management Quality)

4. E (Earnings)

5. L (Liquidity Management)

6. S (Sensitivity)

\subsection{Capital Adequacy}

One of the essential indexes of the bank is capital ratio because it can act as a protector for very potential risk in the bank. With the regard to grown and their future course in general, it is making very important decisions that banking institutions take (Christopoulos, et al., 2011:13).

\subsection{Assets Quality}

The second component of the CAMELS rating system is asset quality because the major cause for most banks which face bankruptcy is the quality of poor assets and its most significant category is known to be the loan portfolio. Therefore, the greatest risk the bank or financial institution is facing is said to be the risk of loan loss which arise from the delinquent loans of the bank. The bank's official must perform the assessment of asset quality with the help of credit risk management and the evaluation of the quality of loan portfolio with the usage of trend analysis and peer comparison must be carried. It is very difficult to measure the asset quality since it is subject to the work or derivation of the bank's analyst (Grier, 2007: 22).

\subsection{Management Quality}

The third component of the CAMELS rating system is management quality in the banking sector which ensures bank's survival and growth. The performance of any firm depends on the key to sound management because management efficiency plays an extremely key role in any organization particularly bank or financial institution. Management quality also energizes 
the management system and respond quickly to an active and changing environment in the organization (Rahman et al., 2018: 124).

\subsection{Earnings}

The following indicators are being used in the analysis of the Earnings (E) as well as profitability in the CAMELS rating system:

Return on Assets (ROA), Return on Equity (ROE) and Cost to Income Ratio (CIR). In generating revenues, the Return on Assets underlines how profitable the bank assets are while Return on Equity (ROE) reflects the profitability of the bank's capital. Therefore, all the values of the indicators must be intercepted with complete caution because high level will underline high profitability but can underline a low level of capitalization whilst a low level would underline a low level of profitability and a high capitalization like vice-versa (Evans, et al., 2000:7). With the regard to the cost to income ratio expenses, the capacity of the bank will cover its operating expenses from income generated and it is compounded by dividing the operational costs to the operations incomes of the bank.

\subsection{Liquidity Management}

The fifth component of the CAMELS rating system is liquidity. Liquidity which is the most significant component for a financial institution or bank is and it has very significant impact on the bank's financial structure. The liquidity constitutes one of the crucial elements which evaluates the operational performances of a financial institution of bank because it expresses bank's capacity to pay its short term debts and face unexpected withdrawals of depositors. (Roman et al., 2013:706).

\subsection{Sensitivity}

The last component of the CAMELS rating system is Sensitivity to Market Risk which assesses the bank on sensitivity toward market risk examining the extent with potential changes to the interest rates, foreign-currency Exchange risk, selling prices and product purchase, all affect the profits or revenue of the financial institution or bank and as well as the value of its all assets (Christopoulos, et al., 2011:13). Most banks or financial institutions consider these changes in interest rates as a market risk (Ghazavi et al., 2018: 857).

\section{CAMELS PERFORMANCE EVALUATION}

The CAMELS criteria as an indicator in the measurement of financial performance to be used in the analysis below are presented in six groups. There are a total of 15 sub-criteria in six groups and their weights obtained from expert opinions and literature research are presented in Table 1. It is worth noting that when different criteria and different weight ratios are used, the results may vary.

Table 1. CAMELS Performance Evaluation Indicators and Weight

\begin{tabular}{|c|c|l|c|c|}
\hline NO & \multicolumn{1}{|c|}{ INDICATORS } & Max/Min & $\begin{array}{c}\text { Weight } \\
(\%)\end{array}$ \\
\hline $\mathbf{1}$ & C- Capital Adequacy & & \\
\hline & C1 & Capital Adequacy Ratio & Max & 0.09 \\
\hline & C2 & Shareholder's Equity/Total Assets & Max & 0.07 \\
\hline & C3 & (Equity - Fixed Assets)/Total Assets & Max & 0.07 \\
\hline
\end{tabular}


BOZDOĞAN, ODABAŞ \& SHEGIWAL

\begin{tabular}{|c|c|l|c|c|}
\cline { 2 - 3 } 2 & A- Asset Quality & \multicolumn{2}{l|}{} & \\
\hline & A1 & Fixed Assets/Total Assets & Max & 0.04 \\
\hline & A2 & NPL(Gross)/Cash Loans & Min & 0.09 \\
\hline & A3 & Financial Assets (Net)/Total Assets & Max & 0.05 \\
\hline 3 & M- & Total Loans and Advances/Total Assets & 0.05 \\
\hline & M1 & Total Loans/Total Deposits & Max & 0.07 \\
\hline & M2 & Profit Per Employee (Profit after Tax/No of Employees) & Max & 0.06 \\
\hline & M3 & Profit Per Branch (Profit after Tax/No of Branch) & Max & 0.06 \\
\hline 4 & E- Earnings & & \\
\hline & E1 & Net Profit/Loss / Total Assets & Max & 0.08 \\
\hline & E2 & Net Profit/Loss / Shareholder's Equity & Max & 0.08 \\
\hline 5 & L- Liquidity Management & & \\
\hline & L1 & Liquid Assets / Total Assets & Max & 0.06 \\
\hline & L2 & Liquid Assets / Short Term Liabilities & Max & 0.06 \\
\hline 6 & S- Sensitivity & & \\
\hline & S1 & Net Interest Income/Total Assets & Max & 0.07 \\
\hline
\end{tabular}

The data has been obtained from the annual reports of all banks mentioned here. The data which obtained from the annual reports for each year, a total of 15 financial performance criteria were calculated in six groups. For example, the calculation for 2018 is presented in the Appendix. After calculating the ratios, it passed through the application of TOPSIS method.

\section{EVALUATION OF FINANCIAL PERFORMANCE WITH TOPSIS METHOD}

TOPSIS, which is one of the multi-criteria decision making techniques, was initially introduced by Yoon and Hwang for the first time and following the appraisal of surveyors and various operators worldwide. TOPSIS is known as decision making technique. It is, in fact, a goal-based approach for finding alternatives which is closest to ideal solutions. Therefore, in this method, based on ideal solution similarity, options are graded, and if an option is likely more similar to the ideal solutions, then it will have a higher grade. Further, and ideal solution is considered to be the best from any aspect which does not exist in terms of practical so its approximation is hereby attempted.

Fundamentally, if we want to measure similarity of a design or option to one of the ideal or non-ideal levels, then we try to consider the distance of that specific design from the ideal and non- deal levels of solutions (Ghasempour and Salami, 2016:56). It is observed that TOPSIS method is entirely and widely used in various and many fields from the evaluation to the financial performance of technology companies to factory location selection. (Bozdoğan, et al., 2016:482).

The TOPSIS method is performed in 7 steps presented below (Ghasempour et al., 2016:5657; Akyüz, et al., 2011:77-80).

1054 
Step 1. Formation of the decision-matrix; below is the structure of the matrix which can be expresses as given below;

$$
A=\left(a_{i j}\right)=\left(\begin{array}{cccc}
a_{11} & a_{12} & \ldots & a_{1 n} \\
a_{21} & a_{22} & \ldots & a_{2 n} \\
\vdots & \vdots & \vdots & \vdots \\
a_{m 1} & a_{m 2} & \ldots & a_{m n}
\end{array}\right)
$$

where $a_{i j}$ is the element of the decision matrix for $i$ the alternative in $j$ the attribute.

Step 2. With the normalization of decision making matrix $B=\left(b_{i j}\right)$, the following formula is used.

$$
b_{i j}=\frac{a_{i j}}{\sqrt{\sum_{k=1}^{m} a_{k j}^{2}}}
$$

Step 3. In order to construct the weighted normalized decision-matrix, the following formula is used by multiplying the normalized decision matrix and its associated weights.

$$
C=\left(c_{i j}\right)=\left(\begin{array}{cccc}
w_{1} b_{11} & w_{2} b_{12} & \ldots & w_{n} b_{1 n} \\
w_{1} b_{21} & w_{2} b_{22} & \ldots & w_{n} b_{2 n} \\
\vdots & \vdots & \vdots & \vdots \\
w_{1} b_{m 1} & w_{2} b_{m 2} & \ldots & w_{n} b_{m n}
\end{array}\right)
$$

Step 4. In order to determine the positive ideal solution $C^{+}$and as well as negative ideal solution $C^{-}$, the following formula is used.

$$
\begin{aligned}
& C^{+}=\left(c_{1}^{+}, c_{2}^{+}, \ldots, c_{n}^{+}\right)=\left(\left(\max _{i} c_{i j} \mid j \in I\right),\left(\min _{i} c_{i j} \mid j \in J\right)\right) \\
& C^{-}=\left(c_{1}^{-}, c_{2}^{-}, \ldots, c_{n}^{-}\right)=\left(\left(\min _{i} c_{i j} \mid j \in I\right),\left(\max _{i} c_{i j} \mid j \in J\right)\right)
\end{aligned}
$$

Step 5. In this step, calculate the separation measures and the separation of each alternative from one of the positive ideals is provided below: 


$$
d_{i}^{+}=\sqrt{\sum_{j=1}^{n}\left(c_{i j}-c_{j}^{+}\right)^{2}} \quad i=1,2, \ldots m
$$

Likewise, the separation of every alternative is given below from the negative ideal.

$$
d_{i}^{-}=\sqrt{\sum_{j=1}^{n}\left(c_{i j}-c_{j}^{-}\right)^{2}} \quad i=1,2, \ldots m
$$

Step 6. With the below formula, relative closeness to the ideal solution shall be calculated as given below:

$$
e_{i}^{+}=\frac{d_{i}^{-}}{d_{i}^{-}+d_{i}^{+}}
$$

Step 7. In the last step, rank the preference order.

The results obtained with the TOPSIS method for each bank for 2014-2018 are shown in Table 2 below.

Table 2. Annual results of TOPSIS method

\begin{tabular}{|l|c|c|c|c|c|}
\hline \multicolumn{1}{|c|}{ Banks } & $\mathbf{2 0 1 4}$ & $\mathbf{2 0 1 5}$ & $\mathbf{2 0 1 6}$ & $\mathbf{2 0 1 7}$ & $\mathbf{2 0 1 8}$ \\
\hline Ziraat Bank(ZB)-TURKEY & 0.609296 & 0.607668 & 0.612786 & 0.659596 & 0.639653 \\
\hline Habib Bank(HB)-PAKISTAN & 0.474324 & 0.464458 & 0.453458 & 0.393824 & 0.404503 \\
\hline Intesa Sanpaolo Bank(ISB)-ITALY & 0.29814 & 0.297152 & 0.274256 & 0.323568 & 0.340536 \\
\hline Societe Generale(SB)-FRANCE & 0.319195 & 0.324737 & 0.306957 & 0.328702 & 0.344637 \\
\hline JPMorgan Chase Bank(JPM)-USA & 0.397914 & 0.405137 & 0.391564 & 0.437396 & 0.459734 \\
\hline
\end{tabular}

Considering the results of the TOPSIS method in Table 2, the bank with the highest value indicates the bank with the highest performance. As a result, based on the financial performance, values of banks in all years, the Ziraat Bank has the highest financial performance compared to other banks as it is shown in the table above. In five years, the Ziraat Bank) had the highest performance in 2017 (0.659596) and Intesa Sanpaolo Bank had in 2016 with the lowest performance (0.272566).

The results presented in the table below 3 indicates the five-year average results of the values which were obtained by the application of TOPSIS method.

Table 3. TOPSIS results based on 5-Year Average

\begin{tabular}{|c|c|c|}
\hline Banks & $\mathbf{2 0 1 4 - 2 0 1 8}$ & Rank \\
\hline ZB-TUR & 0.6175163 & 1 \\
\hline HB-PAK & 0.4449709 & 5 \\
\hline ISB-ITA & 0.3045142 & 4 \\
\hline SG-FRA & 0.3244712 & 3 \\
\hline JPM-USA & 0.4145306 & \\
\hline
\end{tabular}

1056 
In all years, the Ziraat Bank ranked first with the average value of (0.6175163) compared to the other banks average financial performance values, whilst, Intesa Sanpaolo Bank (0.3045142) indicated the lowest performance.

In Figure 1, banks' financial performance trends are presented below;

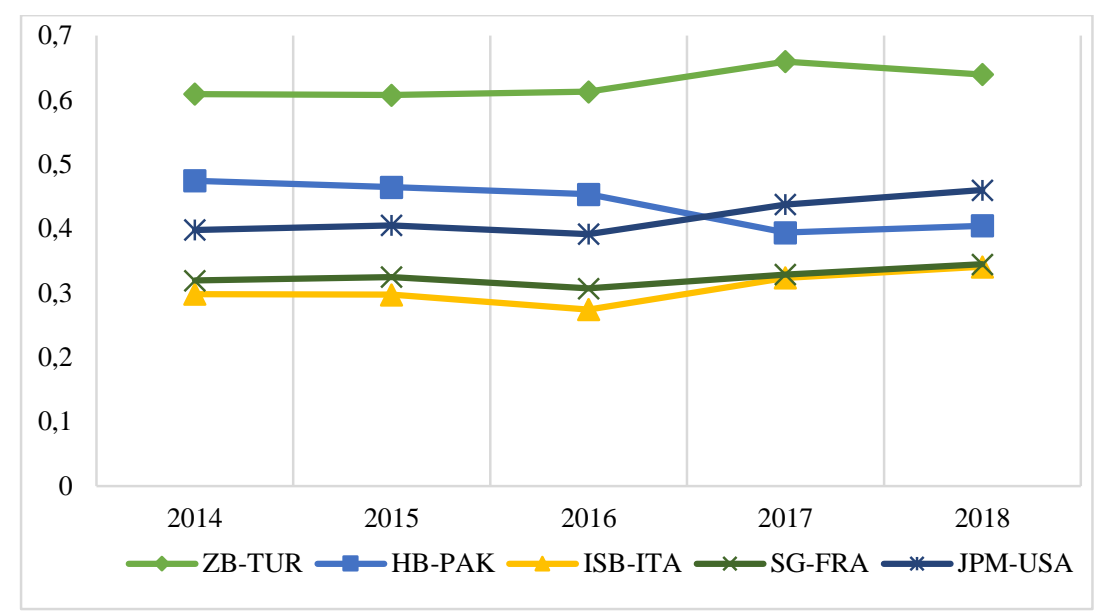

Figure 1. Financial performance trend by years

In Figure 1, it is observed that the performance of Ziraat Bank, which has the highest financial performance, has a general increase on average in 5 years. However, there has been a decrease only in 2018 compared to 2017. Another bank that has shown an increase in its financial performance on a yearly basis is JPMorgan Chase Bank. This bank increased its financial performance especially after 2016. In the flow trend of Habib Bank, it is seen that there is a general decline and a significant decrease in financial performance especially after 2016.

According to ranking among the foreign banks having opened branches in Turkey between 2014-2016 years ahead, while the Habib Bank lost this advantage in 2017 and 2018 and after 2016, Habib Bank, JPMorgan Chase Bank, has surpassed. This situation is also observed after the increase in the performance of JPMorgan Chase Bank after 2016.

In general when the performance trends of the banks are analyzed, it is observed that ranks of the banks have not changed. This situation changed only in 2017. In 2017, JPMorgan Chase Bank moved from the $3^{\text {rd }}$ place to the $2^{\text {nd }}$, while it dropped from the $2^{\text {nd }}$ to the $3^{\text {rd }}$ in Habib Bank.

\section{EVALUATION OF FINANCIAL PERFORMANCE WITH ELECTRE METHOD}

The ELECTRE method, whose acronym stands for ELimination and Choice Expressing REality, was initially introduced by Benayoun, Roy and Sussman (1966) and Roy (1968). The first idea concerning its concordance, discordance and outranking concepts originates from real world applications. Hence, it also usage concordance and discordance guides in order to analyze outranking relations among other alternatives. Therefore, ELECTRE method has been implemented to problems in many arrears consisting environment, energy, finance, 
water management, project selection and decision analysis (Ming-Che $\mathrm{Wu}$ and Ting-Yu Chen, 2011:12319).

Based on the concept of ranking through pairwise comparison between alternative on appropriate criteria, the Multi Criteria Decisions Making ELECTRE method is used and the alternative is supposed to dominate other alternatives whether one or more criteria exceed and becomes equal to the remaining criteria. In order to reduce the number of alternative with a set of alternatives, the basic method of ELECTRE is used which is a sequential procedure that do not dominate. In order to find the best alternative of all criteria, the ELECTRE method requires a weighted knowledge. Below given problem-solving seven steps with ELECTRE method (Yanie, et al., 2018:2).

Step 1. Below is the formula of normalization of Decision Matrix:

$$
b_{i j}=\frac{a_{i j}}{\sqrt{\sum_{k=1}^{m} a_{k j}^{2}}}
$$

Step 2. With the usage of below formula, Normalized Decision Matrix is weighted:

$$
C=\left(c_{i j}\right)=\left(\begin{array}{cccc}
w_{1} b_{11} & w_{2} b_{12} & \ldots & w_{n} b_{1 n} \\
w_{1} b_{21} & w_{2} b_{22} & \ldots & w_{n} b_{2 n} \\
\vdots & \vdots & \vdots & \vdots \\
w_{1} b_{m 1} & w_{2} b_{m 2} & \ldots & w_{n} b_{m n}
\end{array}\right)
$$

Step 3. Determine concordance and discordance set by using function below:

$$
\begin{aligned}
& C_{k l}=\left\{j, c_{k j} \geq c_{l j}\right\}, \text { for } j=1,2,3, \ldots, n \\
& D_{k l}=\left\{j, c_{k j}<c_{l j}\right\}, \text { for } j=1,2,3, \ldots, n
\end{aligned}
$$

Step 4. Concordance $(E)$ and discordance matrix $(F)$ should be calculated, for the first function of concordance matrix as well as for the second discordance matrix:

$$
\begin{gathered}
e_{k l}=\sum_{j \in C_{k l}} w_{j} \\
f_{k l}=\frac{\max _{j \in D_{k l}}\left|c_{k j}-c_{l j}\right|}{\max _{j \in J}\left|c_{k j}-c_{l j}\right|}
\end{gathered}
$$


Step 5. The dominant concordance matrix $G=\left(g_{k l}\right)$ is formed as

$$
g_{k l}=\left\{\begin{array}{lll}
1 & \text { if } & e_{k l} \geq \underline{e} \\
0 & \text { if } & e_{k l}<\underline{e}
\end{array}, i, k \in\{1,2,3, \ldots m\}\right.
$$

e represents the average of dominant matrix elements, by using formula below:

$$
\underline{e}=\frac{1}{m(m-1)} \sum_{k=1}^{m} \sum_{l=1}^{m} e_{k l}
$$

The dominant discordance matrix $H=\left(h_{k l}\right)$ is computed by

$$
h_{k l}=\left\{\begin{array}{lll}
1 & \text { if } \quad f_{k l}<\underline{f} \\
0 & \text { if } \quad f_{k l} \geq \underline{f}
\end{array}, i, k \in\{1,2,3, \ldots m\}\right.
$$

$\underline{f}$ indicates the average of dominant matrix elements, by using formula below:

$$
\underline{f}=\frac{1}{m(m-1)} \sum_{k=1}^{m} \sum_{l=1}^{m} f_{k l}
$$

Step 6. In order to determine the aggregate matrix dominance, the next step is specify dominance aggregate matrix $(P)$ with the usage of multiplication between matrix elements $G$ with $H$ as the function is given below:

$$
p_{k l}=g_{k l} \times h_{k l}
$$

Step 7. When the less favorable alternative is eliminated, it gives the order of selection of each alternative while $p_{k l}=1$ when $p_{k l}$ at least then one $p_{k l}=1$ could be eliminated; therefore, to dominate other options, this is the best alternative.

By examining the rows and columns of the total dominance matrix, the advantages among the alternatives are indicated with the help of shapes in which alternatives are considered as node and the superiorities as arrow sign (vertex). For example, between the three alternatives such as, A, B and as well as C, as shown in the Figure 2 below, direction of the arrows indicates the bilateral superiority. According to superiority, the node (A) from which the arrow exits is interpreted as the superiority of the node (B) it enters. There is no arrow between the nodes that does not have any superiority between each other. Accordingly, it is interpreted as "While A has superiority over B and B has superiority over C no superiority relation between A and C alternatives". 


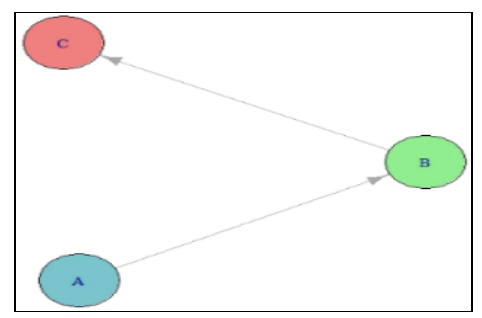

Figure 2. Bilateral superiority graphs

In the below Table 4, the results for the application of ELECTRE method Bilateral Superiority Graphs are shown below;

Table 4. Results of the ELECTRE method by years and Bilateral Superiority Graphs

\begin{tabular}{|c|c|c|c|c|c|c|}
\hline $\begin{array}{c}\text { Banks } \\
2018 \\
\end{array}$ & Concordance & Discordance & $\begin{array}{c}\text { Concordance } \\
\text { Rank } \\
\end{array}$ & $\begin{array}{c}\text { DiscordanceR } \\
\text { ank }\end{array}$ & $\begin{array}{c}\text { Average } \\
\text { Rank }\end{array}$ & 2018-Bilateral Superiority Graphs \\
\hline ZB-TUR & 1.5532 & -2.57228 & 1 & 1 & 1 & \\
\hline HB-PAK & -0.4268 & 0.802861 & 4 & 3 & 3.5 & \\
\hline ISB-ITA & -0.226 & 1.409827 & 3 & 4 & 3.5 & \\
\hline SG-FRA & -1.3292 & 1.666453 & 5 & 5 & 5 & \\
\hline JPM-USA & 0.4288 & -1.30686 & 2 & 2 & 2 & \\
\hline $\begin{array}{c}\text { Banks } \\
2017 \\
\end{array}$ & Concordance & Discordance & $\begin{array}{c}\text { Concordance } \\
\text { Rank } \\
\end{array}$ & $\begin{array}{c}\text { DiscordanceR } \\
\text { ank }\end{array}$ & $\begin{array}{l}\text { Average } \\
\text { Rank }\end{array}$ & 2017-Bilateral \\
\hline ZB-TUR & 1.5964 & -2.69251 & 1 & 1 & 1 & \\
\hline HB-PAK & -0.3468 & 0.776887 & 4 & 3 & 3.5 & \\
\hline ISB-ITA & 0.009 & 1.571189 & 3 & 4 & 3.5 & \\
\hline SG-FRA & -1.6874 & 1.678975 & 5 & 5 & 5 & \\
\hline JPM-USA & 0.4288 & -1.33454 & 2 & 2 & 2 & \\
\hline $\begin{array}{c}\text { Banks } \\
2016 \\
\end{array}$ & Concordance & Discordance & $\begin{array}{c}\text { Concordance } \\
\text { Rank }\end{array}$ & $\begin{array}{c}\text { DiscordanceR } \\
\text { ank }\end{array}$ & $\begin{array}{l}\text { Average } \\
\text { Rank }\end{array}$ & 2016-Bilateral Superiority Graphs \\
\hline ZB-TUR & 1.7142 & -2.95894 & 1 & 1 & 1 & \\
\hline HB-PAK & 0.4312 & 0.557111 & 2 & 3 & 2.5 & \\
\hline ISB-ITA & -0.977 & 1.92232 & 4 & 5 & 4.5 & \\
\hline SG-FRA & -1.2772 & 1.45264 & 5 & 4 & 4.5 & \\
\hline JPM-USA & 0.1088 & -0.97313 & 3 & 2 & 2.5 & \\
\hline $\begin{array}{c}\text { Banks } \\
2015\end{array}$ & Concordance & Discordance & $\begin{array}{c}\text { Concordance } \\
\text { Rank } \\
\end{array}$ & $\begin{array}{c}\text { DiscordanceR } \\
\text { ank }\end{array}$ & $\begin{array}{c}\text { Average } \\
\text { Rank }\end{array}$ & 2015-Bilateral Superiority Graphs \\
\hline ZB-TUR & 1.7546 & -3.05044 & 1 & 1 & 1 & \\
\hline HB-PAK & 0.8232 & 0.701821 & 2 & 3 & 2.5 & \\
\hline
\end{tabular}




\begin{tabular}{|c|c|c|c|c|c|} 
& & & & 5 & 4.5 \\
\hline ISB-ITA & -1.1132 & 1.746352 & 4 & 4 & 4.5 \\
\hline SG-FRA & -1.3894 & 1.610105 & 5 & 2 & 2.5 \\
\hline JPM-USA & -0.0752 & -1.00784 & 3 &
\end{tabular}

\begin{tabular}{|c|c|c|c|c|c|c|}
\hline $\begin{array}{c}\text { Banks } \\
\mathbf{2 0 1 4}\end{array}$ & Concordance & Discordance & $\begin{array}{c}\text { Concordance } \\
\text { Rank }\end{array}$ & $\begin{array}{c}\text { DiscordanceR } \\
\text { ank }\end{array}$ & $\begin{array}{c}\text { Average } \\
\text { Rank }\end{array}$ & 2014-Bilateral Superiority Graphs \\
\hline ZB-TUR & 2.2266 & -3.10553 & 1 & 1 & 1 \\
\hline HB-PAK & 1.0596 & 0.685095 & 2 & 3 & 2.5 \\
\hline ISB-ITA & -1.2908 & 1.529361 & 4 & 4 & 4 \\
\hline SG-FRA & -1.6718 & 1.76719 & 5 & 5 & 5 \\
\hline JPM-USA & -0.3236 & -0.87612 & 3 & 2 & 2.5 \\
\hline
\end{tabular}

In Table 4, average rank values indicate the success order. Halfway values, for example, (2.5) indicates that it is neither 1st nor 3rd. For instance, JPMorgan Chase Bank received the value of 2.5, indicating the average of 1st and 3rd place three times in 2014, 2015 and 2016. Every year, Ziraat Bank became the first with the highest performance based on average rank values. In summary, the average order values taken by the foreign banks having opened branches in Turkey are as followings:

Habib Bank has taken the series ranking value 3 times 2,5 and 2 times 3.5.

Intesa Sanpaolo Bank has taken the series ranking value 2 times 3.5, 2 times 4.5 and 1 time 4 . Societe Generale Bank has taken series the ranking value 2 times 4.5 and 3 times 5 accordingly.

JPMorgan Chase Bank has taken the ranking value 2 times 2 and 3 times 2.5.

The table 5 below, presents the ELECTRE method, average performance results for 20142018 and the Bilateral Superiority Graph for 5 years.

Table 5. ELECTRE Method Results Based on 5-Year Averageand Bilateral Superiority Graph

\begin{tabular}{|c|c|c|c|c|c|c|}
\hline $\begin{array}{c}\text { BANKS } \\
\text { 2014-2018 }\end{array}$ & Concordance & Discordance & $\begin{array}{c}\text { Concordance } \\
\text { Rank }\end{array}$ & $\begin{array}{c}\text { Discordance } \\
\text { Rank }\end{array}$ & $\begin{array}{c}\text { Average } \\
\text { Rank }\end{array}$ & Bilateral Superiority Graph \\
\hline ZB-TUR & 1.8982 & 2.9720491 & 1 & 1 & 1 & \\
\hline HB-PAK & 0.2932 & 0.7291368 & 2 & 3 & 2.5 & \\
\hline ISB-ITA & -0.775 & 1.6488779 & 4 & 5 & 4.5 & \\
\hline SG-FRA & -1.3412 & 1.6427846 & 5 & 4 & 4.5 & \\
\hline JPM-USA & -0.0752 & 1.0487502 & 3 & 2 & 2.5 & \\
\hline
\end{tabular}

In Table 5, according to the ELECTRE method results based on financial performance ranking of 5-year Average, Ziraat Bank ranked $1^{\text {st }}$, Habib Bank and JPMorgan Chase Bank have taken the average rank of 2.5, which is the $2^{\text {nd }}$ and $3^{\text {rd }}$, Intesa Sanpaolo Bank and Societe 
Generale Bank also have taken the average of 4.5 , which is the $4^{\text {th }}$ and $5^{\text {th }}$ rank. While noticing at the Bilateral Superiority Graph for 5 years, the direction of the arrow marks indicates the bilateral superiority relationship and shows the superiority of the bank from which the arrow originates to the bank where the arrow indicates. There is no arrow sign among the banks that do not have a bilateral superiority relationship between them. According to this, the arrow signs from Ziraat Bank to all banks indicates that this bank has a superiority relationship with all other banks and the direction of the arrow signs shows that these banks have higher performance than all of them. While observing other banks, for example, JPMorgan Chase Bank, which received the same average rank (2.5), does not have a bilateral superiority relationship with Habib Bank, but it is in a bilateral superiority relationship with Intesa Sanpaolo Bank and Societe Generale Banks and which is higher than the two of them. Therefore, it appears to have been performed. It is also observed that Intesa Sanpaolo Bank and Societe Generale banks do not have bilateral superiority relations with each other.

\section{CONCLUSION}

Banks are the leading institutions in the general economy. Analysis of the financial performance of banks with scientific methods and continuous evaluation is very important for all information about banks, users and all decision makers directing the country's economy. Banks which have accurate and reliable information about their financial performance can be managed both soundly and fulfill their desired functions in the general economy.

It can be stated that the results of financial performance are generally similar in both methods. While the financial performance ranks and development of the banks are presented in the TOPSIS method over a five-year period, in the ELECTRE method, together with the performance rankings of the banks, their bilateral advantages and affiliations are presented with graphics. In this regard, it is possible to make analysis and evaluations with more detailed and various perspectives. When the results of both methods are analyzed, it has been observed that the Ziraat Bank has the highest financial performance. According to the results of 5 years average financial performance values in TOPSIS method, Ziraat Bank, which has the highest financial performance, is followed by Habib Bank is ranked $2^{\text {nd }}$, JPMorgan Chase Bank is ranked $3^{\text {rd }}$, Societe Generale Bank is ranked $4^{\text {th }}$ and Intesa Sanpaolo Bank is ranked $5^{\text {th }}$.

In the ELECTRE method, Habib Bank and JPMorgan Chase Bank, having the same 2.5 value, follow Ziraat Bank. These banks are followed by Societe Generale Bank and Intesa Sanpaolo Bank, which have the same 4.5 value. In the ELECTRE method, bilateral superiority graphs are also presented to consider the superiority relations between banks and how and in which direction these relations are presented. In the ELECTRE method, the arrow signs from the Ziraat Bank to all other banks indicates the bilateral superiority relationship with these banks while at the same time showing that it has higher financial performance than other banks. However, JPMorgan Chase Bank has bilateral superiority relations both to Societe Generale Bank and Intesa Sanpaolo Bank, but Habib Bank does not have a superiority relationship. Likewise, in the ELECTRE method, it is observed in the bilateral superiority graph that there is no superiority relationship between Habib Bank and JPMorgan Chase Bank which shares the same order with 2.5 values. The same relation can also be seen between Intesa Sanpaolo Bank and Societe Generale Banks. Similar studies on financial performance in different sectors can be conducted using different criteria in the methods. 


\section{REFERENCES}

AHSAN, M. K. (2016). "Measuring Financial Performance Based on CAMEL: A Study on Selected Islamic Banks in Bangladesh”, Asian Business Review, 6(1): 47-56.

AKKOÇ, S. and VATANSEVER, K. (2013). "Fuzzy Performance Evaluation with AHP and TOPSIS Methods: Evidence from Turkish Banking Sector after the Global Financial Crisis", Eurasian Journal of Business and Economics, 6 (11): 53-74.

AKYÜZ, Y., BOZDOĞAN, T. and HANTEKİN, E. (2011). "TOPSIS Yöntemiyle Finansal Performansın Değerlendirilmesi ve Bir Uygulama”, Afyon Kocatepe Üniversitesi İIBF. Dergisi, 13(1): 73-92.

AMILE, M. MAEDEH, S. and POORHOSSEIN, M. (2013). "Performance Evaluation of Banks Using Fuzzy AHP and TOPSIS, Case Study: State-Owned Banks, Partially Private and Private Banks in Iran", Caspian Journal of Applied Sciences Research, 2(3): 128-138.

ANYAECHE, C. and IGHRAVWE, D. (2018). "A Framework for Evaluating the Performance of Automated Teller Machine in Banking Industries: A Queuing ModelCum-TOPSIS Approach", Accounting, 4(2): 53-62.

BAYYURT, N. (2013). “Ownership Effect on Bank's Performance: Multi Criteria Decision Making Approaches on Foreign and Domestic Turkish Banks". Procedia-Social and Behavioral Sciences, 99: 919-928.

BOZDOĞAN, T., ERSOY, B. and KAYGUSUZ, M., (2018). "CAMELS Değerlendirme Sistemiyle Katılım Bankalarının Finansal Performanslarının TOPSIS Yöntemiyle Analizi”, Journal of Social and Humanities Sciences Research, 5(30): 4309-4323.

BOZDOĞAN, T., TAYYAR, N. and ÖNER, Ş. (2016), "Yeni Kamu Mali Yönetim Anlayış1 Perspektifinde Türkiye'de Kamu Kurumları Mali Performanslarının AHP ve TOPSIS Yöntemleriyle Değerlendirilmesi”, Muhasebe Bilim Dünyası Dergisi, 18 (2): 477-514.

CHAUDHURI, T. and GHOSH, I. (2014). Application of Multi-Criteria Decision Making Models in Regulatory Evaluation of Commercial Banks in India and its Consistency with Public Perception. (01.08.2019) https://ssrn.com/abstract=2546647 or http://dx.doi.org/10.2139/ssrn.2546647

CHRISTOPOULOS, APOSTOLOS G., MYLONAKISI J., DIKTAPANIDIS, P. (2011). “Could Lehman Brothers' Collapse Be Anticipated? An Examination Using CAMELS Rating System", International Business Research, 4(2): 11-19.

ÇAĞIL, G. (2011). “2008 Küresel Kriz Sürecinde Türk Bankacıllk Sektörünün Finansal Performansının ELECTRE Yöntemi ile Analizi”, Maliye Finans Yazıları, 25(93): 5986.

ÇALIŞKAN, E. and EREN, T. (2016). "Bankaların Performanslarının Çok Kriterli Karar Verme Yöntemiyle Değerlendirilmesi”, Ordu Üniversitesi, Bil. Tek. Dergisi, 6(2): 85107.

DASH, M. (2016), "Banking Performance Measurement for Indian Banks Using AHP and TOPSIS”, International Journal of Banking and Finance (IIJBF), 12(2): 63-76. 
DEMIRELI, E. (2010). “TOPSIS Çok Kriterli Karar Verme Sistemi: Türkiye'deki Kamu Bankaları Üzerine Bir Uygulama”, Girişimcilik ve Kalkınma Dergisi, 5(1): 101-112.

DINÇER, H. and GÖRENER, A. (2011). "Performance Evaluation Using AHP-VIKOR and AHP-TOPSIS Approaches: The Case of Service Sector", Sigma Journal of Engineering and Natural Sciences, 29(3): 244-260.

DINÇER, H., HACIOĞLU, Ü. and YÜKSEL, S. (2016). "Managerial and Market-Based Appraisal of Agriculture Banking Using ANP and ELECTRE Method". Management and Organizational Studies, 3(3): 29.

DİNÇER, H., YÜKSEL, S., and KARTAL, M. T. (2016). "Evaluating the Corporate Governance Based on Performance of Participation Banks in Turkey with the House of Quality Using an Integrated Hesitant Fuzzy MCDM", BDDK, Bankacılık ve Finansal Piyasalar, 10(1): 9-33.

EGE, İ., TOPALOĞLU, E. E. and KARAKOZAK, Ö. (2015). "CAMELS Performans Değerleme Modeli: Türkiye' deki Mevduat Bankaları Üzerine Ampirik Bir Uygulama”, Niğde Üniversitesi İktisadi ve İdari Bilimler Fakültesi Dergisi, 8(4): 109126.

EVANS, O., ALFREDO M. L., MAHINDER G. and PAUL H., (2000). Macroprudential Indicators of Financial System Soundness, IMF Occasional Paper, No. 192, 7.

GHASEMPOUR, SHIVA, SALAMI, and MOHAMADJAVAD, (2016). "Ranking Iranian Private Banks Based-on The CAMELS Model Using The AHP Hybrid Approach and TOPSIS", International Journal of Academic Research in Accounting, Finance and Management Sciences, 6(4): 52-62.

GHAZAVI, M. and BAYRAKTAR, S., (2016). "Performance Analysis of Banks in Turkey Using-CAMELS Approach Case Study: Six Turkish Banks During 2005 to 2016", İşletme Araştırmaları Dergisi, 10(2): 847-874.

GUAN, F., LIU, C., XIE, F. and CHEN, H. (2019). "Evaluation of the Competitiveness of China's Commercial Banks Based on the CAMELS Evaluation System", Sustainability, 11(6), 1791.

GÜMÜŞ, F.B. and NALBANTOĞLU, Ö. (2015). "Türk Bankacılık Sektörünün CAMELS Analizi Yöntemiyle 2002-2013 Yılları Arasında Performans Analizi”, AKÜ İ̇BF. Dergisi, 17(2): 83-106.

HEMMATI, M., DALGHANDI, S. and NAZARI, H. (2013). "Measuring Relative Performance Of Banking Industry Using a DEA and TOPSIS", Management Science Letters, 3(2): 499-504.

IBRAHIM, M. (2015). "A Comparative Study Of Financial Performance Between Conventional And Islamic Banking in United Arab Emirates". International Journal of Economics and Financial Issues, 5(4): 868-874.

GRIER, W.A. (2007). Credit Analysis of Financial Institutions, 2nd ed. Euromoney Institution Investor Plc., 22-27. 
JAFFAR, M. and MANARVI, I. (2011). "Performance comparison of Islamic and Conventional banks in Pakistan". Global Journal of Management and Business Research, 11(1): 61-66.

KARACA, S. S. and ERDOĞAN, S. (2018). "Türk Bankacilık Sektörünün 2009-2016 Dönemi CAMELS Derecelendirme Sistemi ile Performans Analizi”, Uluslararası Yönetim Eğitim ve Ekonomik Perspektifler Dergisi, 6(3): 23-39.

KARAÇOR, Z. Ö., MANGIR, F., KODAZ, Ş. S. and KARTAL, M. (2017). "Kamusal ve Özel Sermayeli-Bankaların CAMELS Performans Analizi: Türkiye Örneği”, İstanbul Gelişim Üniversitesi Sosyal Bilimler Dergisi, 4(2): 47-65

KARAPINAR, A. and DOĞAN, I. C. (2015). "An Analysis on the Performance of the Participation Banks in Turkey", Accounting and Finance Research, 4(2): 24-33.

KAYGUSUZ, M., ERSOY, B. and BOZDOĞAN, T. (2020). "CAMELS Değerlendirme Sistemiyle Bankaların Finansal Performanslarının TOPSIS Yöntemiyle Analizi”, İnsan ve Toplum Bilimleri Araştırmaları Dergisi, 9(1): 67-95.

KHATRI, K. D., (2019). "CAMELS Ratıng System for Banks a Magnifying lens an Empirical Study in India", International Journal of Tourism and Hotel Business Management, 1(1): 15-27.

KILIÇ, S.B. (2006). "Türk Bankacılık Sistemi için Çok Kriterli Karar Alma Analizine Dayalı Bir Erken Uyarı Modelinin Tahmini”, ODTÜ Gelişme Dergisi, 33: 117-154.

KOMOROWSKI, R. and KUBISZEWSKA, K. (2016). “An Assessment of Islamic Banking in Bosnia and Herzegovina A Comparative Analysis Using the CAMELS Approach", Ekonomia Międzynarodowa, 16: 367-387.

KUMAR, V. and SAYANI, H. (2015). "Application of CAMEL model on the GCC Islamic Banks: 2008-2014”. Journal of Islamic Banking and Finance, 3(2): 1-14.

LI, C. and YE, C. (2014). Comprehensive Evaluation of The Operating Performance for Commercial Banks in China Based on Improved TOPSIS, in 2014 International Conference on-Global Economy, Commerce and Service Science (GECSS-14), Atlantis Press, 17-21

MANJU, R.B. and KUMAR, A.M., (2017). "Adequacy of CAMELS Rating System in Measuring the Efficiency of Banking Industry: A Retrospect", International Journal of Research in Arts and Science, 3: 3-6.

MING-CHE, W. and TING-YU, C. (2011). "The ELECTRE Multicriteria Analysis Approach Based-on Atanassov's Intuitionistic Fuzzy Sets”, Expert Systems with Applications, 38: $12318-12327$.

MOUSA, T. A. (2016). "Measuring Financial Performance Based on CAMEL Rating Model on Islamic Banks in Jordan”, Journal of Advanced Social Research, 6(11): 1-10.

MUNIR, M. B. and BUSTAMAM, U. S. A. (2017). "CAMEL Ratio on Profitability Banking Performance (Malaysia versus Indonesia)". International Journal of Management, Innovation \& Entrepreneurial Research, 3(1): 30-39. 
NIMALATHASAN, B., (2008). “A Comparative Study of Financial Performance of Banking Sector in Bangladesh -An application of CAMELS Rating System", Annals of University of Bucharest, Economic and Administrative Series, No. 2: 141-152.

RAHMAN, Z. and ISLAM, Z. (2018). "Use of CAMEL Rating Framework: A Comparative Performance Evaluation of Selected Bangladeshi Private Commercial Banks", International Journal of Economics and Finance, 10(1): 120-128.

REŞATOĞLU, G. N. (2007). "Financial Ratios and the Probabilistic Prediction of Bank Failure in North Cyprus”, European Journal of Scientific Research, 18(2): 191-200.

ROMAN, A. and ŞARGU A.C. (2013). "Analysing the Financial Soundness of the Commercial Banks in Romania: An Approach Based on the Camels Framework", Procedia Economics and Finance 6: 706.

ROSTAMI, M. (2015). "CAMELS Analysis in Banking Industry", Global Journal of Engineering Science and Research Management, 2(11): 10-26.

ROZZANI, N. and RAHMAN, R. A. (2013). "CAMELS and Performance Evaluation of Banks in Malaysia: Conventional versus Islamic", Journal of Islamic Finance and Business Research, 2(1): 36-45.

SANGMI, M. U. D. and TABASSUM, N. (2010). "Analyzing Financial Performance of Commercial Banks in India: Application of CAMEL model”, Pakistan Journal of Commerce and Social Sciences, 4(1): 40-55.

SARI, T. (2020). "Banka Performans Ölçümünde TOPSIS ve PROMETHEE Yöntemlerinin Karşılaştırılması”, Atatürk Üniversitesi İktisadi ve İdari Bilimler Dergisi, 34(1): 103122.

SEÇME, N. Y., BAYRAKDAROĞLU, A. and KAHRAMAN, C. (2009). "Fuzzy Performance Evaluation in Turkish Banking Sector Using Analytic Hierarchy Process and TOPSIS”, Expert Systems With Applications, 36(9): 11699-11709.

SIEW, L. W., FAI, L. K. and HOE, L. W. (2017). "Evaluation On The Financial Performance Of The Malaysian Banks With TOPSIS Model”, American Journal of Service Science and Management, 4(2): 11-16.

ŞENDURUR, U. and TEMELLİ, F. (2018). “CAMEL Derecelendirme Modeli Yardımı ile Türkiye'de Faaliyet Gösteren Geleneksel Bankalar ve Katılım Bankalarının Karşılaştırmalı Analizi”, Ulakbilge, 6(23): 1-18.

WANKE, P., AZAD, M. A. K., and BARROS, C. P. (2016). "Predicting efficiency in Malaysian Islamic banks: A two-stage TOPSIS and neural networks approach". Research in International Business and Finance, 36: 485-498.

WANKE, P., HASSAN, M. K. and GAVIAO, L. O. (2017). "Islamic Banking and Performance in The Asian Banking Industry: A TOPSIS Approach with Probabilistic Weights", International Journal of Business and Society, 18(SI): 129-150.

YANIE, A., ABDURROZAQ, H., ISHAK, I., MARSONO, M., LUBIS, S., NURMALINI, N., MESRAN, M., NASUTION, S.D., ROBBI R., NURDIYANTO H. and AHMAR, A.S., (2018). Web Based Application for Decision Support System with ELECTRE 
Method, 2nd International Conference on Statistics, Mathematics, Teaching, \& Research IOP Publishing, IOP Conf. Series: Journal of Physics: Conf. Series 1028, 1 10.

www.chase.com

Www.group.intesasanpaolo.com

www.hbl.com

www.societegenerale.com

www.tbb.org.tr/en/modules/banka-bilgileri/banka_sube_bilgileri.asp

www.ziraatbank.com

\section{Appendix. 2018 Year Data (as an example)}

\begin{tabular}{|l|c|c|c|c|c|c|c|c|c|c|c|c|c|c|c|}
\hline \multirow{2}{*}{ Bank } & C- 1 & C- 2 & C- 3 & A- 1 & A- 2 & A- 3 & A- 4 & M- 1 & M- 2 & M- 3 & E- 1 & E- 2 & L- 1 & L- 2 & S- 1 \\
\cline { 2 - 12 } & Max & Max & Max & Max & Min & Max & Max & Max & Max & Max & Max & Max & Max & Max & Max \\
\hline ZB-TURKEY & 14.8 & 10.7 & 12.8 & 0.009 & 2 & 0.08 & 0.69 & 112.3 & 0.27 & 1 & 1.6 & 15.2 & 8.6 & 10.3 & 0.04 \\
\hline HB-PAKISTAN & 16.2 & 0.06 & -21.11 & 21.17 & 7 & 65.84 & 0.35 & 0.5 & 0.61 & 7.13 & 0.4 & 7.1 & 123.3 & 0.13 & 0.02 \\
\hline ISB-ITALY & 16.5 & 0.06 & 0.04 & 0.02 & 1.8 & 0.14 & 0.49 & 0.94 & 0.04 & 0.76 & 0.5 & 8.8 & 0.22 & 0.27 & 0.009 \\
\hline SG-FRANCE & 16.5 & 0.05 & 0.02 & 0.02 & 0.12 & 0.32 & 0.0002 & 0.97 & 0.02 & 0.65 & 0.002 & 7.1 & 1.32 & 1.54 & 0.002 \\
\hline JPM-USA & 15.5 & 0.09 & -0.002 & 0.09 & 0.005 & 2.33 & 0.37 & 67 & 0.12 & 6.44 & 1.24 & 13 & 0.0002 & 0.007 & 0.01 \\
\hline
\end{tabular}

